\title{
THE CYTOCHEMISTRY OF INCLUSION BODIES IN CELL CULTURES INTO WHICH RESPIRATORY SYNCYTIAL VIRUS HAS BEEN INOCULATED
}

\author{
G. Corbitt AND T. S. L. Beswick \\ Department of Bacteriology and Virology, University of Manchester
}

Plate IX

RESPIRATORY SYNCYTIAL (RS) VIRUS induces the formation of polykaryocytes in cell cultures of human and simian origin, and viral replication is generally accompanied by the production of eosinophilic, intracytoplasmic inclusion bodies (Chanock, Roizman and Myers, 1957; Holzel et al., 1963). The inclusion bodies are characteristically surrounded by a clear halo and are, as might be expected, more numerous in syncytia than in single cells (Adams, Imagawa and Zike, 1961; Bennett and Hamre, 1962; Kisch, Johnson and Chanock, 1962). The inclusions have not been shown to stain with acridine orange (Kisch et al.; Hornsleth, 1969), but probably contain virus-specific material (Bennett and Hamre). They resemble in ultrastructure the inclusions seen in cells infected with pneumonia virus of mice (Norrby, Marusyk and Örvell, 1970).

Although the inclusion body produced in cells infected with RS virus has been mentioned repeatedly by previous observers its nature remains obscure. On the assumption that the inclusion body is formed as a consequence of viral replication and either $(a)$ contains virusspecific material, or $(b)$ is a virus-directed host-cell response, investigations of its composition were performed by using a number of cytological techniques.

\section{MATERIALS AND METHODS}

Virus. The strain of RS virus used was the Long strain isolated by Chanock et al. and kindly supplied by Dr J. O'H. Tobin, Public Health Laboratory, Withington Hospital, Manchester.

Cell cultures. HEp 2 cells were obtained from Flow Laboratories Ltd, Irvine, Scotland. U-amnion cells (Berglund and Strahlmann, 1967) were obtained from the Regional Virus Laboratory, East Birmingham Hospital, Birmingham 9, where they had been used successfully for the primary isolation of RS virus from clinical material (Young and Matthews, 1969).

Cells were grown on coverslips at $37^{\circ} \mathrm{C}$ in Eagle's minimal essential medium supplemented with $2 \mathrm{mM}$ L-glutamine and 10 per cent. calf serum and including sodium bicarbonate $(2 \cdot 2 \mathrm{mg}$ per $\mathrm{ml}$ ), sodium benzyl penicillin (100 units per $\mathrm{ml}$ ) and streptomycin $(10 \mathrm{mg}$ per $\mathrm{ml})$. Cultures were maintained in the same medium without serum.

Cells were inoculated at a virus to cell multiplicity of approximately 2.5 to 1 and incubated for 18-24 hr before examination for inclusion bodies.

Cytochemistry. Methyl green-pyronin, Feulgen, periodic acid-Schiff and oil red $\mathrm{O}$ staining were all performed as described by Gurr (1967).

The technique adopted for acridine orange staining was a modification of the method described by Mayor (1964). Acridine orange (G. T. Gurr Ltd, London) was omitted from all stages of the alcohol series with the exception of the initial 90 per cent. alcohol step. The specimens were examined by blue-light fluorescence with an HBO 200 mercury vapour source, a KG 1 heat-absorbing filter, a BG 12 blue-light fluorescence exciter filter and an OG 1 barrier filter. All filters were supplied by Schott and Gen, Mainz.

The nature of any probable nucleic staining was confirmed by digestion with ribonuclease (RNase) or deoxyribonuclease (DNase), either alone (Love and Rabotti, 1963) or in conjunction with pepsin (Mayor, 1963) or pronase. RNase, DNase (BDH Ltd, Poole, Dorset) 


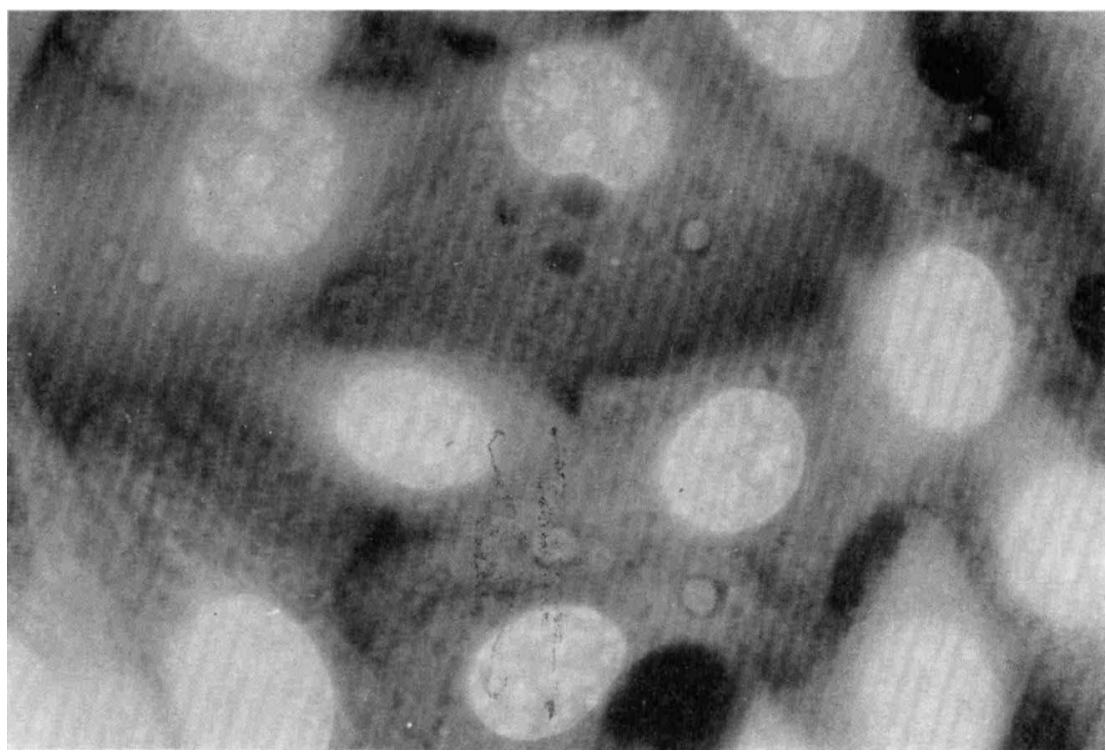

FIGURE.-U-amnion cell monolayer $24 \mathrm{hr}$ after inoculation of $\mathrm{RS}$ virus showing cytoplasmic inclusion bodies. Acridine orange. $\times 1000$. 
and pronase (Koch-Light Laboratories Ltd, Colnbrook, Bucks.) were employed at 0.01 per cent. (w/v) concentration in phosphate-buffered saline (PBS), $p \mathrm{H}$ 7.2. Pepsin (BDH Ltd) was used at 0.002 per cent. (w/v) concentration in 10 per cent. (v/v) acetic acid (Gomatos et al., 1962). The nucleases were allowed to act on Carnoy-fixed cells for $1 \mathrm{hr}$ and the proteases for $5 \mathrm{~min}$. All preparations were washed three times in PBS between enzyme treatments.

Nucleic acid extractions were carried out with 5 per cent. trichloro-acetic acid (TCA) at $90^{\circ} \mathrm{C}$ for $30 \mathrm{~min}$.

\section{RESULTS}

\section{Methyl green-pyronin staining}

The inclusion bodies in the cytoplasm of virus-infected cells stained deep pink by the methyl green-pyronin technique indicating the probable presence of RNA. Prior treatment of fixed preparations with RNase led to reduction or total loss of the staining affinity of the inclusion material; DNase treatment had no effect on its staining reaction. Extraction of fixed preparations with hot TCA prior to staining led to complete removal of the pyroninstainable material.

\section{Acridine orange staining}

Inoculated cells stained by the acridine orange method exhibited an enhanced red fluorescence of the cytoplasm but no obvious changes in nuclear staining, when they were compared with uninoculated control cell cultures. Intracytoplasmic inclusion bodies were clearly distinguishable and emitted a distinct green fluorescence (figure).

Neither enzyme digestion nor treatment with hot TCA abolished the staining affinity of the inclusion bodies. When the concentration of pepsin was increased to 0.02 per cent. (w/v) and a pepsin-nuclease-pepsin treatment procedure was adopted the inclusion material could be shown to lose its staining affinity, although results were extremely variable. This variability was apparent both among different preparations subjected to similar treatments and among different areas of a single preparation.

\section{Feulgen, periodic acid-Schiff and oil red $O$ staining methods}

The inclusion bodies failed to stain by any of these three methods.

\section{Discussion}

The acridine orange staining technique has been applied to cells infected with RS virus by other workers (Kisch et al., 1962; Hornsleth, 1969). In neither case was any success reported; a surprising fact in view of the ease with which the inclusion material stained by this technique during this study. The green fluorescence emitted suggested that the inclusion contains either DNA (Mayor, 1964) or double-stranded RNA (Gomatos et al., 1962), but the enzyme digestion tests employed failed to confirm these possibilities. Treatment with hot TCA, which should extract any nucleic acid present (Schneider, 1945) also failed to affect the acridine orange staining reaction of the inclusion material.

The appearance of deep-pink inclusion bodies after staining with methyl green-pyronin indicates the probable presence of RNA within the inclusions. This is confirmed by the loss of staining reaction when the cells are extracted with hot TCA or digested with RNase before staining. Results with the RNase were variable, and this may indicate the presence of a double-stranded RNA element within some inclusions.

It has been reported that the green fluorescence of reovirus type-3 inclusions in L-cells stained with acridine orange is due not only to uptake of the dye by the viral nucleic acid but also to binding of the dye by protein (Love and Fernandes, 1971). A similar situation may occur in RS-infected cells. Recent electron-microscope studies of Vero cells treated with RS virus have revealed a fibrillar ultrastructure to the inclusion body suggestive of nucleoprotein antigen (Norrby et al., 1970). Thus, there may indeed be a considerable amount of protein present for the masking of nucleic acid. In addition, the variable results obtained with 
acridine orange staining after the pepsin-nuclease-pepsin treatment (pepsin at 0.02 per cent.) suggest that the protease may have modified the protein structure to the point where dyebinding becomes impossible. However, 0.01 per cent. pronase similarly employed had no obvious effect on the subsequent staining reaction of the inclusion material and this enzyme is reported to be particularly effective in breaking down the nucleoprotein structure of the paramyxovirus capsid (Bikel and Duesberg, 1969).

\section{SUMMARY}

Cytoplasmic inclusions produced in cells infected with RS virus appeared to contain RNA, which was stained by the methyl green-pyronin technique. The staining reaction was largely or totally prevented by pre-treatment with RNase. Hydrolysis with hot trichloro-acetic acid invariably removed all the pyronin-stainable material. These facts suggest that although the majority of the RNA present is probably single-stranded there is a small amount of a double-stranded form present. The inclusion material was also shown to exhibit green fluorescence after staining with acridine orange. Neither standard enzyme digestion procedures nor hot TCA extraction abolished the affinity of the inclusion material for acridine orange although variable results were obtained with higher concentrations $(0.02$ per cent.) of pepsin. The green fluorescence is probably due to dye-binding by protein. The inclusion material did not stain by the Feulgen, periodic acid-Schiff and oil red $O$ techniques.

\section{REFERENCES}

Adams, J. M., ImAGaWA, D. T., AND ZIKE, K. 1961. Epidemic bronchiolitis and pneumonitis related to respiratory syncytial virus. J. Amer. Med. Assoc., 176, 1037.

BENNETT, C. R., JR, AND HAMRE, DOROTHY 1962. Growth and serological characteristics of respiratory syncytial virus. J. Infect. Dis., 110, 8.

Berglund, B., and Strahlmann, C. H. 1967. Respiratory syncytial virus infections in hospitalized children. Evaluation of the virus isolation and complement fixation techniques in the virological diagnosis. Clinical and epidemological characteristics. Acta paediat., Stockh., 56, 269.

Bikel, I., AND Duesberg, P. H. 1969. Proteins of Newcastle disease virus and of the viral nucleocapsid. J. Virol., 4, 388.

ChanOCK, R., RoIzMAN, B., AND MYERs, RUTH 1957. Recovery from infants with respiratory illness of a virus related to chimpanzee coryza agent (CCA). I. Isolation, properties and characterization. Amer. J. Hyg., 66, 281.

Gomatos, P. J., Tamm, I., Dales, S., AND Franklin, R. M. 1962. Reovirus type 3: physical characteristics and interaction with L-cells. Virology, 17, 441.

GuRR, G. T. 1967. Biological staining methods, 7th ed., London.

Holzel, A., Parker, L., Patterson, W. H., White, L. L. R., Thompson, K. M., and Tobin, J. O'H. 1963. The isolation of respiratory syncytial virus from children with acute respiratory disease. Lancet, 1, 295.

HoRNSLETH, A. 1969. Growth of respiratory syncytial (RS) virus in HEp-2 cell cultures. Difference in effect of proflavine and actinomycin-D. Acta path. microbiol. scand., 76, 637.

Kisch, A. L., Johnson, K. M., AND ChaNOCK, R. M. 1962. Immunofluorescence with respiratory syncytial virus. Virology, 16, 177.

LOVE, R., AND FERNANDES, M. 1971. Cytochemistry of virus-induced inclusions containing nucleic acids. Proc. Soc. Exp. Biol. Med., 136, 1072.

Love, R., AND Rabotti, G. 1963. Studies of the cytochemistry of nucleoproteins. III. Demonstration of deoxyribonucleic-ribonucleic acid complexes in mammalian cells. J. Histochem. Cytochem., 11, 603.

Mayor, Heather D. 1963. The nucleic acids of viruses as revealed by their reactions with fluorochrome acridine orange. Int. Rev. Exp. Path., $2,1$. 
MAYOR, HeAther D. 1964. A labile intranuclear RNA associated with the development of adenoviruses. J. Exp. Med., 119, 433.

NoRRBY, E., MARUSYK, H., AND ÖRVELL, C. 1970. Morphogenesis of respiratory syncytial virus in a green monkey kidney cell line (Vero). J. Virol., 6, 237.

SChNeIDER, W. C. 1945. Phosphorus compounds in animal tissues. I. Extraction and estimation of deoxypentose nucleic acid and of pentose nucleic acid. J. Biol. Chem., 161, 293.

Young, B. J. J., AND MATthews, R. S. 1969. A comparison of HEp 2 cells and a continuous line of human amnion cells for primary isolation of respiratory syncytial virus. J. Med. Lab. Technol., 26, 93. 